\title{
Exploring the effects of integrated benefit systems and active labour market policies: Evidence from Jobcentre Plus in the UK
}

\section{Eleni Karagiannaki}

\author{
Contents

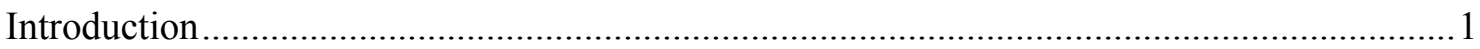 \\ Evidence on Jobcentre Plus service delivery .......................................................... 4

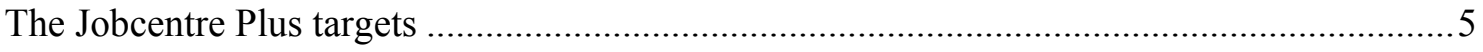

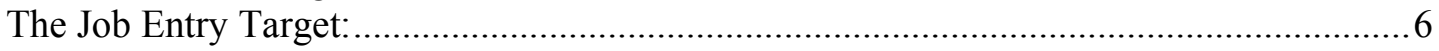

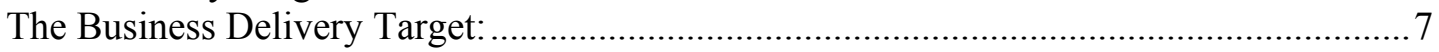 \\ The Monetary Value of Fraud and Error Target: ........................................................

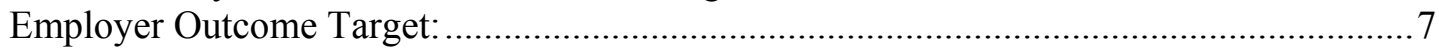

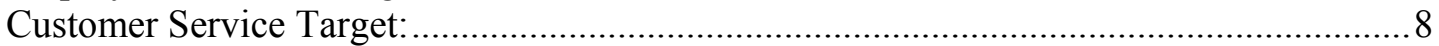 \\ Data \\ Methodology

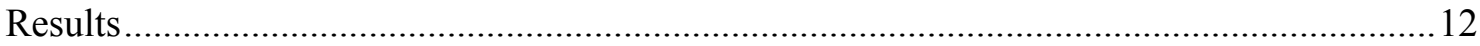

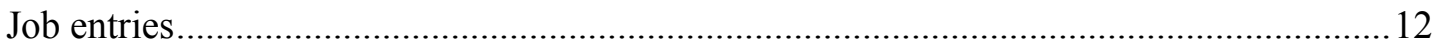

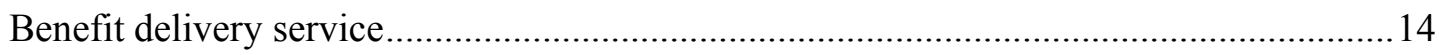

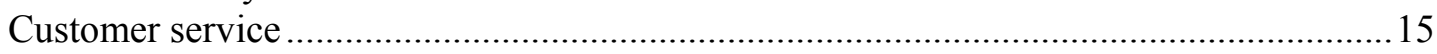

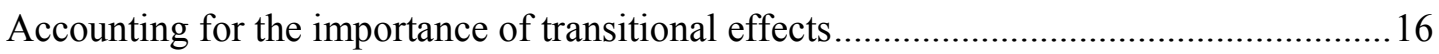

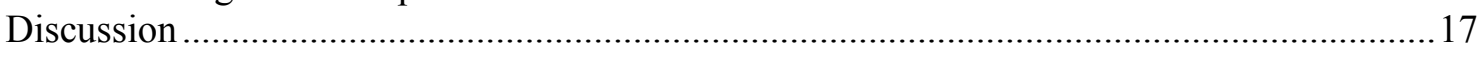

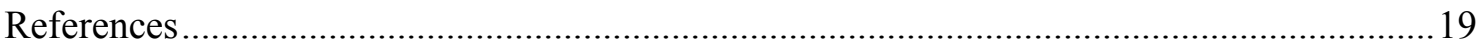

CASE/107

February 2006
Centre for Analysis of Social Exclusion

London School of Economics

Houghton Street

London WC2A $2 \mathrm{AE}$

CASE enquiries - tel: 02079556679 


\section{Centre for Analysis of Social Exclusion}

The ESRC Research Centre for Analysis of Social Exclusion (CASE) was established in October 1997 with funding from the Economic and Social Research Council. It is located within the Suntory and Toyota International Centres for Economics and Related Disciplines (STICERD) at the London School of Economics and Political Science, and benefits from support from STICERD. It is directed by Howard Glennerster, John Hills, Kathleen Kiernan, Julian Le Grand, Anne Power and Carol Propper.

Our Discussion Paper series is available free of charge. We also produce summaries of our research in CASEbriefs, and reports from various conferences and activities in CASEreports. To subscribe to the CASEpaper series, or for further information on the work of the Centre and our seminar series, please contact the Centre Manager, Jane Dickson, on:

$\begin{array}{ll}\text { Telephone: } & \text { UK+207955 6679 } \\ \text { Fax: } & \text { UK+2079556951 } \\ \text { Email: } & \text { j.dickson@lse.ac.uk } \\ \text { Web site: } & \text { http://sticerd.lse.ac.uk/case }\end{array}$

(C) Eleni Karagiannaki

All rights reserved. Short sections of text, not to exceed two paragraphs, may be quoted without explicit permission provided that full credit, including (c) notice, is given to the source. 


\title{
Editorial Note and Acknowledgements
}

Eleni Karagiannaki is a Research Officer at the ESRC Research Centre for Analysis of Social Exclusion. The author would like to thank Tania Burchardt for providing advice and guidance for this research and Howard Glennerster for editing this CASE paper. Any remaining errors and ambiguities are the author's responsibility.

\begin{abstract}
In April 2002 Jobcentre Plus started to operate in the UK bringing together the service of the Benefits Agency and the Employment Service. Offering a fully integrated benefit claiming and work placement/job-seeking service for people of working age this new organisation aims to strengthen the link between welfare and work. Due to the magnitude of the associated organisational change, the national roll-out of the new organisation is being implemented gradually over a transitional period ending in 2006. During this transitional period some local offices are fully integrated while others functions remain split between pre-existing Benefits Agency and Employment Service offices. In this paper we examine how changes in the level of integration (measured as the percentage of offices within districts offering the integrated Jobcentre Plus service) within districts over time affected performance with respect to job entry, benefit service and customer service delivery. Our analysis suggests that Jobcentre Plus has a clear positive effect on job entry outcomes for all client groups, a negative effect on business delivery while it has neither a positive nor a negative effect on customer service outcomes.
\end{abstract}

JEL classification: I38

Keywords: Jobcentre Plus, welfare-to-work, non-jobseekers, policy evaluation. 


\section{Introduction}

Welfare systems throughout Europe and other OECD countries face significant pressures (Finn, 2000). The main contributing factor for this situation has been the increase in the number of people of working age who are dependent on benefits (such as lone parents and the sick and disabled people). Faced with increases in the number of benefit recipients and growing costs of their social assistance and unemployment compensation systems, governments in many countries introduced radical reforms to increase sustainable levels of employment. A major reform strategy in many countries has been the introduction of "welfare-to-work" policies (or activation policies as are alternatively known). In general these policies transform the social security systems from simply providing income replacement cash benefits towards combining this form of provision with training, job search and/or work (OECD, 2003). The main aim of these policies is to create active benefit systems which improve employability, reinforce work incentives and reduce costs and welfare dependency (Finn, 2000).

Traditionally "activation" policies have been applied to working age unemployed people (i.e. to those available for and seeking work). However, faced with the financial pressure caused by the increasing number of inactive benefit claimants, some countries have introduced policies which expanded the number of groups targeted by activation policies (Gilbert, 1992; Gilbert, 2002; Lorentzen, and Dahl, 2005; Scarpetta, 1996; Thornton et al., 1997; OECD, 1996, 1998, 2003). Among the targeted groups are the non-working lone parents, disabled people and other benefit claimants for whom benefit entitlement is not conditional on availability for work. Recent developments in Australia, New Zealand and the UK which required claimants of inactive benefits such as lone parents to attend work-focused interviews can be viewed as part of such "activation" policies. During these work-focused interviews possibilities of work are discussed, job search assistance is provided and referrals to training programmes are made but with no obligation claimants to take-up job offers.

In addition, some governments introduced radical changes to the structure and the management of public employment services (Clasen et al., 2001; Finn, 2000; Martin, 2000). Such changes involve attempts to integrate the operation of agencies responsible for job placement and social assistance services into what are described as "one-stop" or "single gateway" agencies (Finn, 2000). The aim of such attempts is to improve the effectiveness of labour market programmes by creating an integrated gateway to benefit and employment services (Finn, 2000; Clasen et al., 2001). 
Despite the potential benefits of combining these functions under a unified agency and extending the activation policies to a wider group of working age claimants, such attempts carry some potential risks. First, inappropriate pressure may be brought to bear on lone parents and sick and disabled clients. Second, there is a risk that attempts at applying activation strategies to inactive benefits claimants will divert the energies and resources of the Public Employment Services- which are limited, both in terms of staff and in terms of job vacanciesaway from unemployed people as traditionally defined. Third, organisational changes which involve the integration of employment assistance and benefit administration services carry the risk that those working in one or other (or both) of the previously existing agencies will perceive their services as being "taken over", thereby reducing staff morale and commitment to the service (Finn et al., 2005).

It is the latter two issues which are the focus of this paper, and which are going to be addressed based on evidence from Jobcentre Plus, the agency which started to operate in the UK in April 2002 integrating the service of the preexisting Benefits Agency and the Employment Service. Being part of the welfare-to-work policy agenda the main aim was to strengthen the link between welfare and work for a wide range of working age benefit claimants including the unemployed, lone parents, disabled people and carers. Reflecting the workfocus of the policy, all new and repeat claimants claiming a benefit under the administration of Jobcentre Plus are required to attend a work-focused interview for their benefit claims to be processed. Unlike the group of unemployed clients in receipt of Jobseekers Allowance who already have been part of an intensive work-focused service, the changes introduced by Jobcentre Plus significantly altered the experience of non-JSA clients such as lone parents and the sick and disabled.

Prior the creation of Jobcentre Plus, the integration of the benefit claiming and work placements/job-seeking activities was piloted by an agency named ONE. ONE operated in 12 areas of Great Britain during the period from June 1999 to October 2001. Building upon experience gained by ONE, in October 2001, 56 Jobcentre Plus Pathfinder offices started to operate in 17 areas of Britain. The national implementation of Jobcentre Plus started in April 2002. However, because of the magnitude of the associated organisational changes the national roll-out of the new organisation is being implemented gradually over a transitional period which is planned to end in 2006.

During this transitional period some local offices are fully integrated while for others functions remain split between pre-existing Social Security Offices and Jobcentres. Benefit claimants are offered the new service provided that they live in the areas where integrated Jobcentre Plus offices are operating. For clients 
not living in such areas the benefit claiming and job placement services remain split and are provided by their local Social Security Offices and Jobcentres respectively. Jobcentres in such areas provide integrated benefit claiming and job-seeking/job placement services for JSA clients only, while for non-JSA client groups such as the lone parents and the sick and disabled, benefit services are provided by Social Security Offices. In a separate development, since April 2001 mandatory LPWFI (Lone Parent Work-Focused Interviews) were introduced for lone parents claiming Income Support in both integrated and non-integrated Jobcentre Plus offices (Knight and Lissenburg, 2005).

The combination of benefit and work-placement/job-seeking activities means that the service that the Jobcentre Plus has to deliver is multi-dimensional. On the one hand it has to deliver an efficient, accurate and speedy benefit service to all benefit claimants as previously the Benefits Agency had to deliver, whereas at the same time it has to deliver an efficient work-focused service, increasing job entries and the labour market attachment - traditionally an objective of the Employment Service. It is obvious that in such a multi-tasking agency the service delivery depends on the availability of resources and the importance attached to different elements of the Jobcentre Plus service.

Our aim in this paper is to examine the performance of Jobcentre Plus with respect to different elements of service delivery. In particular we seek to examine its performance with respect to three different elements of service:

i) job entry outcomes: measuring performance with respect to job entry

ii) customer service: measuring performance with respect to the general standards of service that is provided to customers

iii) benefit service: measuring the speed and accuracy of the benefit claiming process. In the next section we discuss in detail what each of these indicators is measuring.

The hypotheses that we want to test are the following:

i) Has the integration of benefit claiming and job-seeking activities under a unified agency improved job entry outcomes for a wider group of claimants i.e. those traditionally classed as inactive? If yes, were there any negative effects with respect to job entry outcomes for JSA that would suggest that the extension of activation policies to inactive benefit claimants diverted energies and resources away from unemployed people as traditionally defined?

ii) Is there any evidence that some elements of service have improved at the expense of others?

The latter hypothesis relates to concerns that have been raised by ex-BA staff that the Jobcentre Plus performance targets put an explicit priority to "front office" in contrast with the treatment of the "back office" function of benefit processing (Johnson, 2003; Finn et al., 2005). The prioritisation of "front 
office" under the new organisation to a large extent reflects the high importance attached to the delivery of an efficient work-focused service. In the context of the three elements of service that we examine here, a prioritisation of workfocused service might increase job entry outcomes whereas it could have negative effects on benefit service delivery. The effects on customer service depend on the extent to which staff perceive this element of service to be a prerequisite for the efficient delivery of the work-focused service. Examining Jobcentre Plus performance with respect to different elements of service can thus inform us about the extent to which all elements of the Jobcentre Plus service are effectively accomplished or whether the work-focus of Jobcentre Plus is operating to the detriment of other elements of the service.

Before presenting the results of our testing we review some of the studies examining Jobcentre Plus service delivery, we describe briefly the targets upon which the performance of Jobcentre Plus is measured and we give details on the data and the methods used in our analysis.

\section{Evidence on Jobcentre Plus service delivery}

The Department of Work and Pensions (DWP) has commissioned a series of evaluation research projects to monitor the extent to which Jobcentre Plus is meeting its service delivery and labour market objectives. At the time of writing, DWP has published five research reports based on this evaluation research (Lissenburgh and Marsh 2003; Davies et al., 2004; Coleman et al., 2004; Corkett et al., 2005; McKenna et al., 2005). The various elements of Jobcentre Plus service delivery that have been analysed can be categorised within the following themes: delivery of the work-focus, customer satisfaction, labour market outcomes, office environment, staff safety and fraud. Highly relevant to our analysis is the evidence concerning labour market outcomes and customer service performance presented in Corkett et al. (2005). Comparing the job entry performance of integrated against non-integrated districts, Corkett et al. reach the conclusion that integrated Jobcentre Plus offices performed better in terms of the total number of job entries for disabled people. However they do not find any difference between integrated and non-integrated districts for lone parents or for jobseekers. They attribute this lack of difference between integrated and non-integrated districts to the fact that for these client groups, work-focused interviews are in place in both integrated and non-integrated districts (for lone parents the lone parent work-focused interview has rolled out nationally in April 2002 while jobseekers have always been required to attend a work-focused interview as a condition for the benefit claim). Following a similar approach Corkett et al. find that integration had a negative effect on customer service. This negative effect however was mainly attributable to the 
negative transitional effects that were present during the rollout period, with performance recovering a few months after the initial rollout. Similarly to Corkett et al., we use differences in integrated status in order to examine the effects of the Jobcentre Plus service. However, the approach that we followed to address our research questions is very different. Corkett et al. define an integrated district as any district in which at least one office is integrated. In this paper, rather than focusing on differences between integrated and nonintegrated districts, we use the actual level of integration (defined in terms of the percentage of offices within districts operating as integrated Jobcentre Plus offices) that each district has achieved at each point in time. In addition we examine all three elements of the Jobcentre Plus service delivery (job entry, customer service and business delivery) providing an overall picture of the service delivery. Finally, recognising that the national implementation of Jobcentre Plus can be a disruptive process, we present results isolating possible negative transitional effects resulting from the implementation of Jobcentre Plus.

\section{The Jobcentre Plus targets}

Since 1997, when New Labour came to power the welfare state in the UK has undergone significant reforms. These reforms had an explicit welfare-to-work orientation and were designed to promote employment, foster inclusion and reduce poverty (Taylor-Gooby et al., 2004; Walker and Wiseman, 2003 outline and discuss the effectiveness of various welfare reforms introduced under new Labour). Jobcentre Plus has been a key element of the reform of the welfare state in the UK. Reflecting the ideal "work for those who can, security for those who cannot" (DSS, 1998), which has been central to the New Labour reform of the welfare system, the objectives of the new organisation as they are outlined in the 2002/03 Annual Report and Accounts (Jobcentre Plus, 2003), are the following:

- to put more benefit recipients in touch with the labour market through the intervention of their Personal Adviser

- to increase sustainable levels of employment by getting more benefit recipients into work

- to ensure that people experience effective and efficient service that is tailored to their personal needs

- to change the culture of the benefit system and the general public towards independence and work rather than payments and financial dependence.

In order to promote the successful delivery of its objectives, a series of targets have been set out covering several elements of the Jobcentre Plus service. The five components are: Job Entry, Customer Service, Employer Outcome, 
Business Delivery and Monetary Value of Fraud and Error. Each of these targets is briefly outlined below.

\section{The Job Entry Target:}

According to 2003/04 Jobcentre Plus Business Plan each district should achieve a total points score of 7,681,000 based on the job entry outcomes that it achieves. The job entry target is based on a point system that signals priority groups (see Table 1). Each client group and employment programme was allocated a point score with highest weight attached to job entries for clients from priority groups and programmes. Client groups with highest weights are jobless lone parents including people on the New Deal for Lone Parents, those on New Deal for Disabled People, people with disabilities in receipt of a specified primary benefit and other people in receipt of a specified benefit. There are additional scores for:

- job entries achieved for unemployed customers who live in disadvantaged areas, defined on the basis of a high proportion of ethnic minorities or the poorest labour market status and low income ( 2 additional points)

- Jobseeker Allowance clients who remain off benefit 4 weeks after starting the job (1 additional point) (Johnson, 2003).

Table 1: Job entry target point system 2003/04

Priority Client Group 1: Job entry point score 12

Jobless Lone Parents including people on the New Deal for Lone Parents

Those on the New Deal for Disabled People

People in receipt of a specified primary benefit (Income Support, Incapacity

Benefit, Severe Disability Allowance, Invalidity Care Allowance and Bereavement Benefit)

Priority Client Group 2: Job entry point score 8

People on the New Deal 50 plus

People on the New Deal 25 plus

Those on the New Deal For Young People

Employment Zones

Other people with Disabilities not included in Priority Client Group 1

JSA (Jobseeker's Allowance) long term claimants (over 6 months)

Priority Client Group 3:Job entry point score 4

JSA short term claimants (under 6 months)

Priority Client Group 4:Job entry point score 2

Unemployed non claimants

Priority Client Group 5:Job entry point score 1

Employed people

Note: Job entry target for 2003/04 was 7,681,000 points 


\section{The Business Delivery Target:}

The Business Delivery target was designed to ensure that Jobcentre Plus undertakes its activities in an efficient and effective manner. This target consists of five components:

- accurate processing of claims of Income Support (assessed by checking a sample IS claims),

- accurate processing of claims for Jobseeker's Allowance (measured by checking a sample of JSA claims),

- accurate and timely processing of Incapacity Benefit Medical Testing decisions (timeliness is measured through IT systems while accuracy is assessed by specialised teams for a sample of IB claims)

- booking appointments and holding interviews with clients and following up cases where clients have failed to attend interviews (measured by reviewing regionally a sample of cases)

- identification of people in certain client groups who have literacy, language and numeracy skill needs through a face to face screening process (measured as the proportion of specific client group that have been screened. In 2003/04 the latter component of the Business Delivery target changed slightly so that it now measures attendance of a client at independent assessment following a basic skill referral. The screening element is implicit to this version of the target as it needs to happen before a client can be referred for an assessment).

For 2003/04 the target was that the Jobcentre Plus business processes are delivered efficiently, accurately and to the specified standards in 88 per cent of the cases checked.

\section{The Monetary Value of Fraud and Error Target:}

This target was set to reduce customer fraud, customer mistake and official error. Specialist teams visit each district 3 times a year to examine a number of randomly selected IS and JSA cases (Burgess et al., 2003). The target for the 2003/04 operational year was to reduce losses from fraud and error in working age Income Support and Jobseeker Allowance to no more than 6.9 per cent of the monetary value of these benefits paid during this year.

\section{Employer Outcome Target:}

The two main indicators making up the employer outcome measure are:

- resolution, which indicates that the vacancy was filled from any source (making up $75 \%$ of the whole target) and

- responsiveness, which indicates whether the vacancy was filled in a timescale that met the employers' need (representing $25 \%$ of the target).

For 2003/04 the target was to achieve a positive outcome for at least 82 per cent of employers who place their vacancy with Jobcentre Plus. 


\section{Customer Service Target:}

The Customer Service target was designed to measure the performance of Jobcentre Plus in meeting the standards and commitments outlined in the Jobcentre Plus Customer and Employer Charters. The four elements upon which it is measured are the following:

- speed - how quickly staff answer telephone, greet customers and deal with customers on the telephone and face to face

- accuracy - the accuracy of information given over the telephone and face to face,

- proactivity - how well the organisation understands customers' requests, anticipates their needs and how successfully services are tailored to meet their individual needs,

- environment - the quality, facilities, and accessibility of the premises.

This target is divided into two areas: service to clients (assessed in terms of all four elements outlined above) and service to employers (assessed in terms of speed, accuracy and proactivity). Service to clients accounts for 75 percent of the whole target while service to employers accounts for 25 percent of the target. For the client service component performance is assessed by independent research companies and is measured via a mystery shopping approach (Burgess et al., 2003). For the employers' service component performance is assessed by independent contractors through an employer telephone questionnaire (Burgess et al., 2003). For 2003/04 the target was to achieve an 83 per cent customer service level in the delivery of the standards set out in the Customers' and Employers' charters.

\section{Data}

Each year Jobcentre Plus publishes data on performance indicators for each of the above listed targets. For our evaluation we use district level performance indicators on job entry, customer service and business service for 2002/03 and 2003/04.

Job entry performance indicators are published on a quarterly basis and are used to evaluate the effect of the integrated Jobcentre Plus service on labour market outcomes. Two types of data are offered to describe performance with respect to job entry:

- the total job entry points score which is an aggregate indicator of performance derived using different weights for job entries achieved for different client groups (according to the prioritisation presented in Table 1) and

- the actual number of job entries for each client group. 
We use the absolute number of job entries that was achieved for each client group (unemployed, lone parents and disabled people) as a percentage of the total number of clients that comprised each group. There are two main reasons for choosing job entries as a percentage of the relevant customer base rather than using total job entry point score. Firstly, using the percentage of job entries for each client group allows us to examine whether Jobcentre Plus had a different impact for different client groups (something that would not be feasible looking at job entry point score). Secondly, job entry point score does not take into account differences in the customer base across districts or within districts over time. Thus, relying on job entry point score we would probably pick up differences in customer base among districts or within districts over time.

Performance indicators with respect to customer service and business delivery are used to examine our second hypothesis. Benefit service delivery is examined exploiting information on performance for three of the components of the business delivery target i) accurate processing of claims for Income Support, ii) accurate processing of claims for Jobseeker's Allowance and iii) accurate and timely processing of Incapacity Benefit Medical Testing decisions. ${ }^{1}$ For customer service we use an aggregate indicator summarising the performance with respect to all components of the Customer Service target. Similarly to job entry, customer service performance data are available on a quarterly basis, while the three elements of business delivery target are available on a fourmonthly basis.

\section{Methodology}

As discussed earlier the Jobcentre Plus national rollout has been a gradual process which was planned to be implemented in several stages. In April 2002, when Jobcentre Plus started to operate, only a limited number of offices offered a fully integrated work placement and benefit claiming service. Among the 90 districts only the 17 Pathfinder districts had any integrated Jobcentre Plus office in April 2002. ${ }^{2}$ The second stage of the national implementation of Jobcentre Plus was planned to be implemented between October 2002 and March 2003

with the rollout of new integrated Jobcentre Plus offices across twenty-four

1 Performance data for the job entry and customer service targets are available from the Jobcentre Plus website. Data on business delivery and its components were kindly provided by Jobcentre Plus Research Division Directorate.

2 The average number of offices within districts is about 15 offices with a minimum of 5 and a maximum of 42 offices. 
districts (some of which included Pathfinder offices). The third (2003/04) stage of the roll-out began in April 2003. The planning horizon is that by the end of 2005/06, new Jobcentre Plus offices will operate in all districts. In the meantime, services continue to be provided by local Social Security Offices and Jobcentres, which form part of the Jobcentre Plus network but otherwise continue to provide the same service that they provided before the introduction of Jobcentre Plus.

Figure 1: Percentage of districts by degree of integration

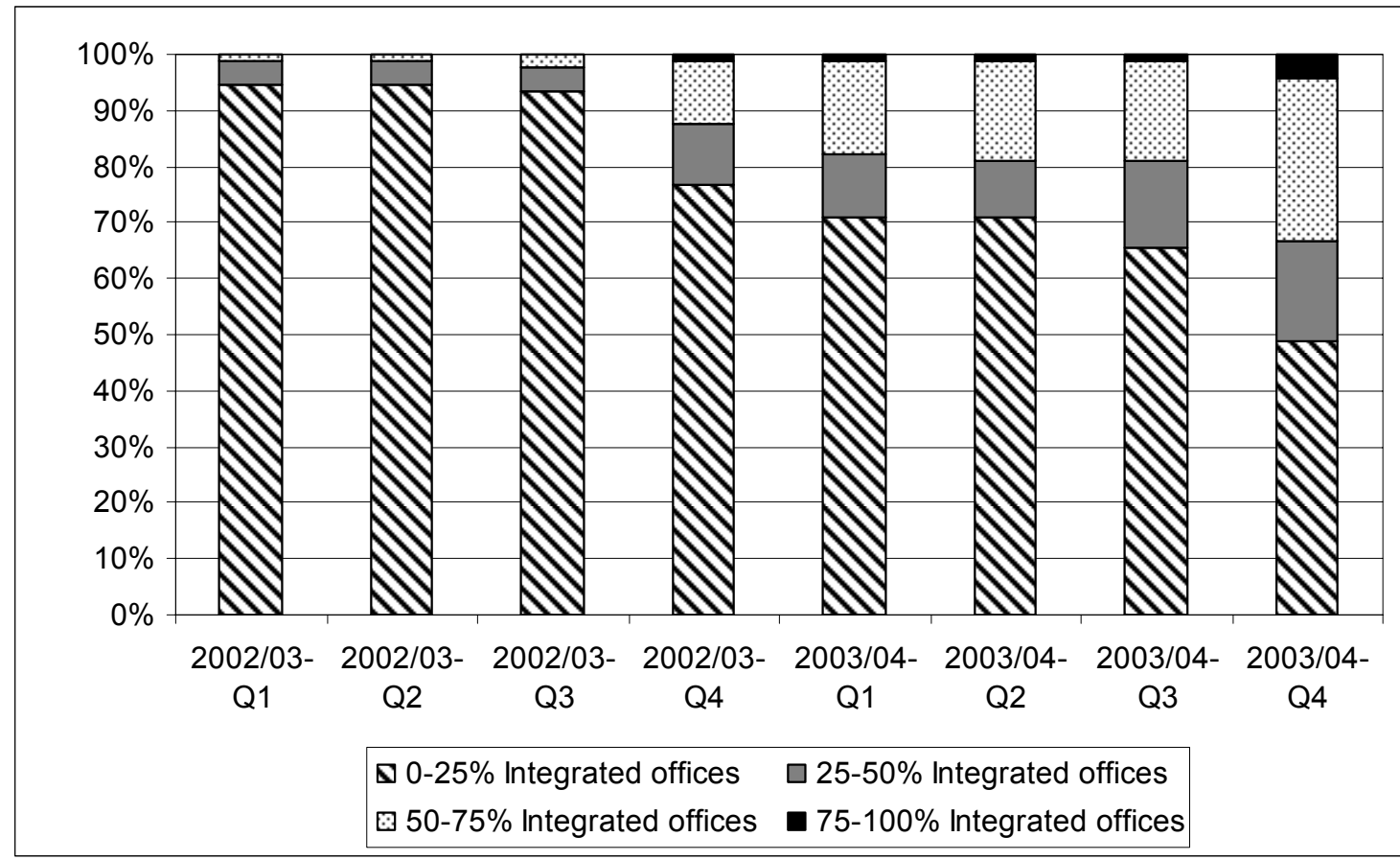

To provide a graphical description of the integration process Figure 1 shows the percentage of districts with different levels of integration for each quarter from April 2002 to March 2004. ${ }^{3}$ As it is evident from this figure in the first quarter of 2002/03, the majority of districts had only very few offices offering the integrated Jobcentre Plus services. By the end of the observation period (fourth quarter of 2003/04) there had been significant increases in the percentage of districts with a higher proportion of integrated Jobcentre Plus offices. However, even then a high proportion of districts had a relatively low level of integration

3 The level of integration of districts is defined as the proportion of offices within districts that have been rolled-out as integrated offices by the end of each quarter. To construct this measure we used information on dates that offices have been rolled out as integrated offices and the total number of offices within districts. Data were kindly provided by the Department of Work and Pensions. 
(in about 49 percent of districts less than 25 percent of offices operate as integrated Jobcentre Plus offices).

The gradual roll-out of offices offering the new integrated service can be used as a natural experiment to test the effect of integration on the performance outcomes. Ideally in order to test the impact of integration upon job entries, customer service and benefit service delivery we would need information on how changes in the integrated status have affected the performance of individual offices. Unfortunately data providing information on performance of individual offices are not publicly available. Our testing is therefore based on a series of regressions on a dataset that includes quarterly (four monthly) district level performance statistics. We include a variable measuring the districts' integration level at the beginning of each quarter (four month period), measured as the percentage of offices within district offering the integrated Jobcentre Plus services. In addition we include a dummy variable indicating Pathfinder districts. Given that Pathfinder districts first piloted the Jobcentre Plus service we might expect that they would adjust earlier than other districts to changes.

For each of the performance indicators that we examine here we present results from two models. The first is a pooled ordinary least squares (OLS) model which treats each observation as an independent observation. The second model is a fixed effects model which accounts for the fact that there are multiple observations per district. The latter model analyses differences within a given district over time. Its main advantage is that it differences out any fixed district characteristics across the time periods and thus eliminates the heterogeneity bias, which may result if there are unobserved district specific effects that may affect both the degree of integration and performance (e.g. having an enthusiastic district manager). This may be of particular importance if the selection of districts for early integration has not been random.

These are very simple models, focusing attention on how differences in degree of integration can account for differences in the performance among districts or within districts over time. Due to their simple nature these models explain a small proportion of the overall variation. More sophisticated models, using more explanatory variables (such as local labour market conditions, and measures of staffing levels) would increase their explanatory power, as indicated by the R-squared values. Unfortunately, labour market data are not available at Jobcentre Plus district level. Nevertheless, these simple models provide useful insights for the hypotheses that we seek to test here.

Our approach has several advantages over the one followed by Corkett et al. (2005). Firstly, whereas Corkett et al. examine differences in the performance of integrated and non-integrated districts (defined in term of whether there are any 
integrated Jobcentre Plus offices within districts) we test the effect of integration taking into account the level of integration within districts (\% of offices operating as integrated Jobcentre Plus offices). Secondly, our fixed effects models allow us to take account of unobserved district level characteristics. In particular if those districts selected for a greater degree of integration early on in the national roll-out period were not typical of all districts, a pooled OLS regression may over or understate the true impact of integration on service delivery.

\section{Results}

\section{Job entries}

We begin our analysis by looking at the effects of the level of integration on job entry outcomes. The hypothesis that we want to test is whether the integration of benefit claiming and job-seeking activities under a unified agency has improved job entries. The OLS and fixed effects estimates for the effect of the degree of integration on the overall performance with respect to job entry are presented in Table 2.

Table 2: The impact of Jobcentre Plus on job entries outcomes

\begin{tabular}{lcc}
\hline \hline & Pooled OLS & Fixed Effect \\
\hline Integrated status & 0.0011 & $0.0062 * * *$ \\
Pathfinder & 0.116 & \\
Constant & $3.595 * * *$ & $3.567 * * *$ \\
& & \\
Obs. & 720 & 720 \\
Number of districts & 90 & 90 \\
R-squared & 0.005 & 0.003 \\
\hline \hline
\end{tabular}

Note: $* * *$ significant at $1 \% ; * *$ significant at $5 \% ; *$ significant at $10 \%$

Examining first the effect of integration using OLS estimation we find that the integrated status variable has no significant effect on job entries. This result suggests that districts which are more fully integrated do not achieve higher job entries than the less fully integrated districts. In contrast to the pooled OLS model, the estimated coefficient on integrated status from the fixed effect model suggests that the integrated status has a statistically significant positive effect on the job entry outcomes: a 1 percentage point increase in the number of integrated Jobcentre Plus offices within a district increases job entries by about 0.0062 percentage points. The difference in the effects of integrated status variable captured by the pooled OLS and fixed effect model is consistent with 
the idea that there are unobservable differences between integrated and nonintegrated districts. As we discussed earlier, in addition to the integrated status variable in the regressions we include a variable indicating districts with Pathfinder offices. Although we might expect that Pathfinder districts would adjust earlier than other districts to changes given that they first piloted the Jobcentre Plus service, the pooled OLS estimators does not suggest that Pathfinder districts perform any better than non-Pathfinder districts with respect to job entry outcomes. Pathfinder status is time-invariant so it is dropped from the FE estimation.

Table 3: The effect of Jobcentre Plus on the job entry outcomes for different clients groups

\begin{tabular}{|c|c|c|c|c|c|c|}
\hline & \multicolumn{2}{|c|}{ Unemployed } & \multicolumn{2}{|c|}{ Lone Parents } & \multicolumn{2}{|c|}{ Sick/disabled } \\
\hline & OLS & $\begin{array}{l}\text { Fixed } \\
\text { Effect }\end{array}$ & OLS & $\begin{array}{l}\text { Fixed } \\
\text { Effect }\end{array}$ & OLS & $\begin{array}{l}\text { Fixed } \\
\text { Effect }\end{array}$ \\
\hline $\begin{array}{l}\text { Integrated } \\
\text { status }\end{array}$ & 0.0022 & $0.0111^{* * *}$ & 0.0022 & $0.0101^{* * *}$ & $0.0041^{* * *}$ & $0.0048^{* * *}$ \\
\hline Pathfinder & $0.53 *$ & & -0.02 & & -0.04 & \\
\hline Constant & $9.25 * * *$ & $9.28 * * *$ & $3.15 * * *$ & $3.07 * * *$ & $0.25 * * *$ & $0.23 * * *$ \\
\hline Obs. & 720 & 720 & 720 & 720 & 720 & 720 \\
\hline $\begin{array}{l}\text { Number of } \\
\text { districts }\end{array}$ & 90 & 90 & 90 & 90 & 90 & 90 \\
\hline R-squared & 0.008 & 0.005 & & 0.001 & 0.151 & 0.146 \\
\hline
\end{tabular}

Note: $* * *$ significant at $1 \% ; * *$ significant at $5 \% ; *$ significant at $10 \%$

As stressed by Corkett et al. (2005) the effect of integration should be larger for the group of sick and disabled clients and smaller for the jobseekers and lone parents - given that for the latter two client groups there is no major difference in the intervention regime between integrated and non integrated offices. ${ }^{4}$

Our results concerning the effect of integration on the job entry outcomes for different client groups are presented in Table 3. Similarly to the results presented in Corkett et al. (2005), the OLS estimates suggest that the effect of integration is significant for the group of the sick and disabled clients while it is insignificant for jobseekers and lone parents. However, the fixed effect estimates reveal a somewhat different picture: the degree of integration has a

4 As discussed earlier the lone parents work-focused interview has rolled out nationally in April 2002 while for jobseekers have always been required to attend a work-focus interview as a requirement for the benefit claim. 
significant positive effect on the job entry outcomes for all the three client groups with unemployed clients experiencing the highest increase in terms of job entry outcomes. For this group the fixed effect estimate on the integrated status variable suggests that a 1 percentage point increase in the number of offices within districts offering the integrated Jobcentre Plus services increases job entries by about 0.0111 percentage points. Although Jobcentre Plus has a significant positive effect on the job entry outcomes for lone parents and the sick and disabled people, the magnitude of the increase for these groups is lower than the one we find for jobseekers: the increase implied by the coefficient on the integrated status variable is 0.0101 and 0.0048 percentage points for the client groups of lone parents and the group of the sick and disabled people respectively. Increasing job entries is a positive outcome signalling that the integration of benefit claiming, job-seeking and work placement activities under a single agency is an effective policy for increasing employment for a wider group of benefit recipients. We do not find any support for the conjecture that the extension of activation policies to a wider group of inactive benefit claimants would have negative effects on the job entries of JSA clients. On the contrary, the results of the fixed effect models suggest that as the percentage of integrated Jobcentre Plus offices within districts increases the job entries among JSA clients increase as well. Differences between the pooled OLS and the fixed effect estimates suggest that there are unobservable district effects that affect both the level integration and performance. Eliminating these effects using a fixed effect model increases the effect of integration level on job entries outcomes for all client groups.

\section{Benefit service delivery}

Having examined the impact of Jobcentre Plus on job entry outcomes we now turn to investigate its effects on outcomes relating to the delivery of benefit services. The hypothesis that we want to test here is whether the emphasis attached to the delivery of a more efficient work-focused service has been at the expense of benefit service delivery. Table 4 presents results on the effect of integrated status on the three components of the business delivery target that relate to the accuracy of three different benefit types: JSA, IS, IB (the main benefits for the unemployed, lone parents and the disabled people respectively).

For all the three benefits under examination results from both the pooled OLS and fixed effect models suggest that higher degree of integration is associated with lower accuracy of benefit processing. According to the fixed effects model a one percentage point increase in the percentage of integrated offices within the district decreases accuracy performance by $0.0337,0.0393$ and 0.0877 percentage points for JSA, IS and IB benefits respectively. This finding supports the hypothesis that the work-focus of the new organisation is to the detriment of business delivery. 
Table 4: The impact of Jobcentre Plus on benefit service delivery

\begin{tabular}{|c|c|c|c|c|c|c|}
\hline & \multicolumn{2}{|c|}{ JSA accuracy } & \multicolumn{2}{|c|}{ IS accuracy } & \multicolumn{2}{|c|}{ IB Accuracy } \\
\hline & OLS & $\begin{array}{l}\text { Fixed } \\
\text { effect }\end{array}$ & OLS & $\begin{array}{l}\text { Fixed } \\
\text { effect }\end{array}$ & OLS & $\begin{array}{l}\text { Fixed } \\
\text { effect }\end{array}$ \\
\hline $\begin{array}{l}\text { Integrated } \\
\text { status }\end{array}$ & $-0.0305^{* *}$ & $-0.0337^{* *}$ & $-0.0271^{* *}$ & $-0.0393^{* * *}$ & $-0.0671^{* * *}$ & $-0.0887^{* * *}$ \\
\hline Pathfinder & -0.39 & & $1.60^{* * *}$ & & $1.77 * *$ & \\
\hline Constant & $92.93^{* * *}$ & $92.89 * * *$ & $91.70^{* * *}$ & $92.14^{* * *}$ & $98.86^{* * *}$ & $99.46^{* * *}$ \\
\hline Obs. & 539 & 539 & 539 & 539 & 485 & 485 \\
\hline $\begin{array}{l}\text { Number of } \\
\text { districts }\end{array}$ & 90 & 90 & & 90 & 90 & 90 \\
\hline R-squared & 0.017 & 0.017 & 0.015 & 0.001 & 0.053 & 0.041 \\
\hline
\end{tabular}

Note: Missing values for the IB accuracy performance for the first two quarters results in a significantly lower number of observations for IB accuracy equation.

$* * *$ significant at $1 \% ; * *$ significant at $5 \%$; significant at $10 \%$.

These results concerning the negative impact of integration on business delivery have to be treated with caution since they might reflect transitional problems caused by disruption and reorganisation following the integration process. The possible importance of such transitional effects is reflected in the OLS estimate on the variable indicating Pathfinder districts. This estimate suggests that Pathfinder districts achieve a better accuracy performance for IS and IB than do non-Pathfinder districts. In the next section we examine the importance of such transitional effects more closely by providing results for the integrated status after eliminating the importance of transitional effects.

\section{Customer service}

The final performance measure which we examine is customer service (Table $5)$.

Given that good customer service is a precondition for the delivery of an efficient work-focused service we might except that the work-focus would have positive spill-over effects on customer service. Despite its importance, results from both OLS and the fixed effect models suggest that integrated status has a significant negative effect on customer service. When we eliminate the unobserved district effects a 1 percentage point increase in the number of offices within districts offering the integrated Jobcentre Plus services is found to decrease the customer service performance indicator by 0.0323 percentage points. Unlike the results concerning the job entry outcomes, the results on customer service suggest that Pathfinder districts achieve a slightly better 
performance than non-Pathfinder districts lending support to the idea that transitional effects may be important.

Table 5: The impact of Jobcentre Plus on customer service

\begin{tabular}{lcc}
\hline \hline & Pooled OLS & Fixed Effect \\
\hline Integrated status & $-0.0210^{* *}$ & $-0.0323^{* * *}$ \\
Pathfinder & $1.105^{* *}$ & \\
Constant & $83.656^{* * *}$ & $83.988^{* * *}$ \\
& & \\
Obs. & 720 & 720 \\
Number of districts & 90 & 90 \\
R-squared & 0.0087 & 0.0191 \\
\hline \hline
\end{tabular}

Note: ${ }^{* * *}$ significant at $1 \% ; * *$ significant at $5 \% ; *$ significant at $10 \%$

\section{Accounting for the importance of transitional effects}

In the analysis of the previous section we have used differences in the percentage of offices within districts operating as integrated Jobcentre Plus offices in order to investigate the impact of integration on various performance indicators. Although differences in the percentage of integrated Jobcentre Plus offices provide important statistical information to identify the impact of Jobcentre Plus on various performance indicators it may produce misleading results if there are negative transitional effects associated with the creation of new integrated Jobcentre Plus offices. Such transitional effects are to be expected given the large organisational changes that were necessary in order to deliver the new service.

In order to disentangle any negative transitional effects, in this section we present results from models estimated after eliminating those observations in which the degree of integration has changed since the previous observation. Basing our estimation on those observations for which the integration status is constant for at least one quarter (or in the case of the benefit service delivery indicators a four months period) we eliminate the potential negative transitional effects associated with the change.

Results from the fixed effects model on job entry and customer service outcomes are presented in Table 6 . When we eliminate transitional effects associated with periods during which new integrated offices have been rolledout, the coefficient on integrated status for job entry outcomes increases to 0.0099 (compared to 0.0062). The increase in the effect of integrated status compared to the model that did not account for transitional effects indicates that there are indeed negative transitional effects. In contrast to the results presented 
in Table 4, which indicated that degree of integration had a significant negative effect on customer service, the second column of Table 5 suggests that after eliminating transitional effects the impact of integrated status variable on customer service is insignificant.

Table 6: Fixed effect models estimating the impact of Jobcentre Plus on job entries and customer service and benefit service delivery after eliminating transitional effects

\begin{tabular}{lccccc}
\hline \hline & Job entry & $\begin{array}{c}\text { Customer } \\
\text { Service }\end{array}$ & $\begin{array}{c}\text { JSA } \\
\text { accuracy }\end{array}$ & $\begin{array}{c}\text { IS } \\
\text { accuracy }\end{array}$ & $\begin{array}{c}\text { IB } \\
\text { Accuracy }\end{array}$ \\
\hline Integrated status & $0.0099^{* * * *}$ & $0.0077^{* * *}$ & $-0.0496^{* *}$ & $-0.0676^{* * *}$ & $-0.0739^{* * * *}$ \\
Constant & $3.576^{* * *}$ & $83.872^{* * *}$ & $93.11^{* * *}$ & $92.13^{* * *}$ & $99.33^{* * *}$ \\
& & & & & \\
Obs. & 657 & 657 & 474 & 474 & 420 \\
$\begin{array}{l}\text { Number of } \\
\text { districts }\end{array}$ & 90 & 90 & 90 & 90 & 90 \\
R-squared & 0.014 & 0.003 & 0.005 & 0.004 & 0.020 \\
\hline \hline
\end{tabular}

Note: $* * *$ significant at $1 \% ; * *$ significant at $5 \%$; significant at $10 \%$

On the other hand, for the benefit service delivery the results presented in Table 6 suggest that even when we isolate transitional effects, the degree of integration has a significant negative effect on performance with respect to each of the three benefits under consideration. Thus, for the benefit service delivery, the negative effect of integrated status does not seem to be a transitional but rather reflect more permanent features of the system.

\section{Discussion}

The importance of integrated management of benefit systems and active labour market policies under an agency which combines the three core functions of job placement, benefit payments and placing participants on active labour market programmes has been widely stressed by international organisations. It is argued that combining these functions can extend the activation policies to a wider group of working age claimants who otherwise will be difficult to reach. Despite the potential benefits of combining benefit and work placement activities, such attempts carry the risk that the emphasis put on the delivery of a work-focused service will have negative effects on the delivery of the benefit service. 
In this paper we evaluate the impact of integrating the benefit and job seeking activities under a unified agency on various aspects of service delivery, based on evidence from the Jobcentre Plus which started to operate in the UK in April 2002. Due to the magnitude of the required organisational change, the rollingout of new Jobcentre Plus offices is being implemented gradually. During a transitional period which is planned to end by 2006 , services are provided by new integrated Jobcentre Plus offices as well as by pre-existing local Social Security Offices and Jobcentres, which continue to provide the same service that they provided before the introduction of Jobcentre Plus. Here we exploited changes in the degree of integration within districts over time in order to evaluate the impact of the integrated Jobcentre Plus service on three performance measures: job entries, customer service and benefit service delivery (evaluated in terms of accuracy of three different benefits). Our analysis suggests that after eliminating significant transitional effects, the integrated Jobcentre Plus service has a clear positive effect on job entry outcomes for all client groups while it has neither a positive nor a negative effect on customer service outcomes. In line with the argument that the new integrated service and the work-focus of the new organisation would have negative effects on elements of the service relating to the benefit claiming process, we find that the accuracy of processing claims for the JSA, IS and IB benefits (the principle benefits for unemployed, lone parents and sick and disabled people respectively), are negatively affected by Jobcentre Plus.

Overall our analysis suggests that despite the positive labour market outcomes, there is an unmet need for an adequately resourced "back office" functions, in order for the benefit service not to be affected negatively by the change and the emphasis placed on the delivery of an efficient work-focused service. In addition, given the negative transitional effects that we found for Jobcentre Plus for job entries and customer service as well as benefit delivery governments and policymakers in other countries should take special care when designing multitasking organisations such as Jobcentre Plus to guard against the disruption to services associated with major organisational change. 


\section{References}

Burgess S. C. Propper, M. Ratto and E. Tominey (2003), Incentives in the public sector: Evidence from a Government agency, CMPO Working Paper 03/080, University of Bristol

Clasen J., G. Duncan, T. Eardley, M. Evans, Pascal Ughetto, W. Oorschot and S. Wright (2001), 'Towards "single gateways"? A cross-national review of changing roles of employment offices in seven countries', Zeitschrift fuer Internationales und Auslaendisches Sozialrecht, 15(1): 43-63

Coleman N., N. Rousseau and H. Carpenter (2004), Jobcentre Plus Service Delivery Survey, IAD Social Research Division Research Report No. 223

Corkett, J., S. Bennett, J. Stafford, M. Frogner and K. Shrapnell (2005), Jobcentre Plus evaluation: Summary of evidence, IAD Social Research Division Research Report No. 252

Davies V., J. Taylor, Y. Hartfree and K. Kellard (2004), Delivering the Jobcentre Plus vision: Qualitative research with staff and customers (Phase 3), IAD Social Research Division Research Report No. 222.

DSS (Department of Social Security) (1998), New ambitions for our country: A new contract for welfare, $\mathrm{Cm} 3805$, London: The Stationery Office.

Finn, D. (2000), 'Welfare to work: the local dimension', Journal of European Social Policy, 10(1): 43-57

Finn, D., M. Knuth, O. Schweer and W. Somerville (2005), Reinventing Public Employment Service: The changing role of employment assistance in Britain and Germany, Anglo-German Foundation for the Study of Industrial Society

Gilbert, N. (1992), 'From entitlement to incentives: the changing philosophy of social protection', International Social Security Review, 45(3): 5-17

Gilbert, N. (2002), Transformation of the Welfare State. The Silent Surrender of Public Responsibility. Oxford: Oxford University Press.

Jobcentre Plus (2003), Jobcentre Plus Annual report and Accounts. http://www.jobcentreplus.gov.uk

Johnson S. (2003), Jobcentre Plus Performance Targets: A Review of the Evidence 2000-2002, Policy Research Institute Leeds Metropolitan University

Knight, G. and S. Lissenburg (2005), Evaluation of the extension of to Lone Parent Work-Focused Interviews eligibility: Administrative data analysis, IAD Social Research Division Research Report No. 237. 
Lissenburgh, S. and A. Marsh (2003), Experiencing Jobcentre Plus Pathfinders: Overview of early evaluation evidence, DWP In-House report No. 111

Lorentzen, T. and E. Dahl (2005), 'Active labour market programmes in Norway:are they helpful for social assistance recipients?', Journal of European Social Policy, 15(1): 27-45

Martin, P. J. (2000), What work among active labour market policies: Evidence from OECD countries' experiences, OECD Economic Studies Paper No. 30

McKenna, K., A. Slater, J. Steels and H. Walton (2005), Delivering the Jobcentre Plus vision: Qualitative research with staff and customers (phase 4), IAD Social Research Division Research Report No. 253

OECD (1996), The OECD Jobs Strategy: Enhancing the effectiveness of Active Labour Market Policies, Paris: OECD.

OECD (1998), Key Employment Policy Challenges Faced by OECD Countries, Labour Market and Social Policy Occasional papers 3, Paris: OECD.

OECD (2003), Benefits and employment, Friend or Foe? Interactions between active and passive social programmes, in OECD Employment Outlook: 2003

Scarpetta, S. (1996), 'Assessing the role of labour market policies and institutional settings on unemployment: a cross-country study', $O E C D$ Economic Studies, 26(1): 43-98.

Taylor-Gooby, P. T. Larsen and J. Kananen (2004), 'Market Means and Welfare Ends: The UK Welfare State Experiment', Journal of Social Policy, 33(4): 573-592

Thornton, P., Sainsbury, R. and Barnes, H. (1997), Helping Disabled People to Work: A Cross-National Study of Social Security and Employment Provisions, SSAC Research Paper 8, London: The Stationery Office

Walker, R. and M. Wiseman (2003), 'Making welfare work: UK activation policies under New Labour', International Social Security Review, 56: 329 